reproductions de documents. Il est regrettable que la majorité des photographies reproduites soient datées du $\mathrm{XX}^{\mathrm{e}}$ siècle.

Micheline Dumont

Professeure émérite

Université de Sherbrooke

James T. Patterson. Brown v. Board of Education: A Civil Rights Milestone and its Troubled Legacy. Oxford University Press, 2001. Pp. 318.

This is the first volume in a new series entitled Pivotal Moments in American History, published by Oxford University Press. Each book in the series investigates "a historical problem through the lens of a particular event and the choices of individual actors," while reflecting the "current state of historical writing," including the use of "ordinary people, increasing sensitivity to issues of gender, class, and ethnicity, and deep interest in large structures and processes" (p. xi). Through the use of a variety of characters and perspectives, James T. Patterson provides a thorough historical investigation of Brown v. Board of Education of Topeka. Patterson weaves the themes identified in his title throughout the entire book as he searches for possible answers to understanding this particular historical problem in the time periods before, during, and after Brown v. Board. In the end, Patterson leaves the reader with a rich understanding of the complexity of Brown as a major historical event not only in education, but also in terms of civil rights.

Reading Brown v. Board reminded me of a conversation I recently had with fellow educators at a conference. Our discussion began with the current state of desegregation in Kansas City, a situation Patterson discusses in his concluding chapter. From there, our discussions led quickly to an evaluation of Brown v. Board. A firm believer in the importance of racial integration, I couldn't help but walk away from the conversation with a feeling of disappointment at the limited success of Brown. Patterson captures this feeling while reminding me of the great strides that have been 
made in social equality as a result of Brown. He argues, however, while many advances have been made in social equality and justice, much has been left unresolved.

Patterson begins by examining the historical context of Brown. In chapter one, he captures the realities of the Jim Crow South, highlighting disparities in education. Drawing on the works of Zora Neale Hurston and W.E.B. DuBois, Patterson shines light on the origins of Brown v. Board. Can Black children receive a proper education in White institutions? Is public education even the best ground for this battle? In chapter two, Patterson notes significant court cases that preceded Brown v. Board, as well as grass-roots movements and struggles to overturn the infamous separate-butequal doctrine of Plessy v. Ferguson.

Chapters three through six focus on the setting for both Brown $I$ and Brown II. Chapter three describes the characters involved in the Supreme Court at the time. Here, Patterson explores the politics and power struggles ongoing behind the scenes of Chief Warren's deeply divided Court and the landmark verdict striking down Plessy v. Ferguson, recognizing "separate educational facilities are inherently unequal" (p. 67). Chapter four begins by discussing the great promise and possibility of the Brown verdict. The impact of the Court's ruling, however, was not as promising as originally hoped. Desegregation was met with great hostility in the South. In chapter five, Patterson specifically addresses the stories of Southern Whites resisting desegregation. Through the leadership of elected officials, segregationists found victory in the Briggs case ruling:

"Brown did not require integration, only the end of state-sponsored segregation" (p. 115). This ruling proved to be a blow to the desegregation movement, but it was not crippling. In chapter six Patterson returns to the uncertainty that preceded and followed Brown v. Board. While Jim Crow laws were now unconstitutional, the racial attitudes and deep division between Blacks and Whites still prohibited progress towards racial integration in some areas of the country, especially the South.

In chapters seven through ten Patterson brings the Brown $v$. Board decision to present-day issues. Chapter seven discusses the surprises of the Burger Court. Civil rights supporters worried that Justice Burger, a republican, would quickly lead the Court to the right. However, Burger's Court pushed the idea of desegregation even further with decisions on busing and white flight in both the North and the South. In the end, integrationists were left wondering just how much change Brown v. Board could bring about while noticing the price paid by the loss of Black institutions, 
leadership, and traditions in order to achieve racial integration. Chapter eight is entitled "Stalemates." This short chapter looks at the change in national leadership with the election of President Ronald Reagan followed by President George Bush, their "sporadic battles against affirmative action" (p. 171), and other civil rights policies that have slowed down the progress experienced in the ' $60 \mathrm{~s}$ and '70s.

Chapter nine addresses the issue of resegregation. Here, Patterson brings to the forefront of the discussion the issue of de facto segregation. In the evolution of the struggles Patterson has presented concerning the troubled legacy of Brown v. Board, he finally addresses, though not as directly as I had hoped, the role of human nature in desegregation. Specifically, Patterson discusses de facto segregation and the difficulties of trying to desegregate a population that has chosen to segregate itself. Busing, while successful in some cities, has proven to be a great obstacle that complicates the desegregation of those who do not want to be desegregated. Chapter ten then concludes with legacies and lessons to learn from Brown v. Board. While it is difficult at times to celebrate the success of Brown $v$. Board in light of current segregation trends in housing and education, Patterson reminds the readers that there is still much to appreciate. Even though we have not achieved full racial integration in our society or even our schools, Brown was a milestone for great changes in American society, including the end of Jim Crow, the migration of many Blacks out of impoverished areas of the South, the ignition of the Civil Rights Movement, economic growth, expansion of public schools, and the growth of White liberal attitudes.

Patterson's timely work, with a rich appendix of resources, provides a balanced, historical perspective arguing both sides of the debate surrounding the impact of Brown v. Board. As we approach the fiftieth anniversary of Brown v. Board, it is prudent to remember the lessons of its complex, troubled, yet celebrated history. Fifty years ago, our society operated under the idea of separate but equal and the reality of separate and unequal. How far are we from that reality today and at what cost? Patterson ends his book with a quote from Jack Greenberg, one worthy of stating again: "Altogether, school desegregation has been a story of conspicuous achievements, flawed by marked failures, the causes of which lie 
beyond the capacity of lawyers to correct. Lawyers can do right, they can do good, but they have their limits. The rest of the job is up to society" (p. 223).

Tracy J. Schuster

St. Ambrose University

\section{Antonia McManus. The Irish Hedge School and Its Books, 1695-1831. Dublin: Four Courts Press, 2002. Pp. 270.}

During the seventeenth century the Irish lost a few key battles to invading English forces. Those losses had a significance that is difficult to underestimate, for they led to the destruction of the old Gaelic society and paved the way for dispossession and centuries of repressive foreign domination. The penal laws, imposed by Britain on Ireland during the reign of William III (1689-1702), virtually placed Catholics outside of the law. Practitioners of the despised "popery," the vast majority of the population, were forbidden to teach so that the country might be more easily subjected to Protestant proselytism and Anglo assimilation. The hedge schools, so called because they were often conducted outdoors and in remote places out of sight of the British overlords, were part of Ireland's resistance to the colonial project. This book by Antonia McManus is the first substantial and comprehensive study of these unique educational institutions and is to be welcomed for its thorough scholarship, balanced judgement, and fine writing.

The hedge schools had their heyday in the eighteenth century and represented the determination of the Irish, in spite of poverty, to seek an education for their children. The system, if such it could be called, was private and non-sectarian in nature and usually functioned through a community pooling its resources to hire a teacher. As the penal laws were relaxed in the latter half of the century, the schools were able to move indoors and the teachers could advertise their services in newspapers. The British authorities may have become more tolerant, but they never really approved of the schools. Their great fear was that Irish children were learning their own history and "enmity to England, hatred of the government, and superstitious veneration for old and absurd 